\title{
DOCUMENTOS NORMATIVOS E ORIENTADORES DA EDUCAÇÃO BÁSICA: a nova $B N C C$ e o ensino de química
}

\author{
Jacqueline Querino Alves \\ Prefeitura Municipal de Ribeirão Preto \\ Tássia Joi Martins \\ Universidade Federal de São Carlos \\ Joana de Jesus Andrade \\ Universidade de São Paulo
}

\begin{abstract}
Resumo
O presente trabalho consiste na análise dos atuais documentos orientadores da educação básica, no âmbito da disciplina Química no Ensino Médio. Foram analisados: os Parâmetros Curriculares Nacionais para o Ensino Médio (PCNEM) e seus complementos (PCN+), assim como a Proposta Curricular do Estado de São Paulo para a Disciplina de Química e a atual Base Nacional Comum Curricular (BNCC). Os conteúdos, bem como as habilidades previstas, para este nível de ensino foram estudados considerando-se a construção sócio-histórica da área de conhecimento da Química na Educação Básica. O estudo objetivou uma análise de interface entre os diferentes textos na busca de identificação de convergências e divergências entre os documentos. Os resultados permitem concluir que o novo formato trazido pela BNCC proporcionou: a diminuição da ênfase da disciplina de Química no Ensino Médio; a redução do conteúdo de Química e; a realocação de muitos conteúdos da disciplina deste nível de ensino para o Ensino Fundamental.
\end{abstract}

Palavras-chave: BNCC; PCNEM; PCN+; Proposta Curricular do Estado de São Paulo; Ensino de Química.

\begin{abstract}
The present work consists in an analysis of the actual guiding teaching and learning documents in basic education level, related to chemistry field at the high school. We investigated: National Curricular Parameters for high school (PCNEM), their complements (PCN+), Sao Paulo State curriculum proposal for Chemistry and the actual Curricular Common National Basis (BNCC). The expected contents and competences were studied considering the socio-historical construction of Chemistry learning in Basic Education. The study analyzed the interfaces between the different texts for identification of convergences and divergences between the documents. The results allow us to conclude that the new teaching format, introduced by the BNCC, promoted: decreasing of emphasis of the Chemistry discipline at the high school level; reducing of Chemistry contents and the reallocation of many contents of Chemistry to Elementary School.
\end{abstract}

Keywords: BNCC; PCNEM; PCN+; Sao Paulo State curriculum proposal; Chemistry contents. 


\section{Introdução}

A Escola, enquanto instituição, tem sua história marcada pela conjuntura entre as legislações que a ela coordenam e as práticas diárias de seu funcionamento. Entre as leis e as práticas, a distância pode ser discursiva, mas mais que isso, é concreta na vivência das pessoas e nas repercussões sociais, políticas e econômicas dessa interconstituição. E, no cenário de sempre "novas Leis", desde 2017 a comunidade escolar e a sociedade brasileira, de modo geral, aguardam a finalização e as definições de uma nova Base Nacional Comum Curricular que promete trazer mudanças significativas e promover as tão esperadas melhorias no Ensino Médio brasileiro. Novamente, como já visto em outros momentos da história da educação brasileira, Leis e Práticas se entrelaçam no campo das ideias e no "chão da escola" e, na luta (tácita) de poder, explicitam-se ainda nossos modos de fazer educação em um país com uma longa lista de demandas por fazer.

No bojo das acaloradas discussões, que datam de muitos anos, surgem os argumentos acerca da quantidade excessiva de disciplinas no currículo (13); do baixo percentual de alunos no ensino técnico (menos de 10\%); da reduzida inserção de alunos no ensino superior (cerca de 15\%); da estagnação do IDEB (Índice de Desenvolvimento da Educação Básica) na maioria das escolas; e do desempenho insatisfatório nas avaliações promovidas pelo PISA (Programa Internacional de Avaliação de Estudantes), comparativamente a países em situação econômica considerada menos favorável que o Brasil (Silva, 2018; Bittencourt, 2017). Para cada tema supracitado, surgem vários questionamentos que perpassam tanto a viabilidade econômica das propostas quanto os meandros de funcionamento, a formação específica dos professores, as características das avaliações nacionais e internacionais e mesmo a exequibilidade da proposta em função das diferenças regionais de um país com a extensão territorial brasileira. Assim, qualquer proposta que se coloque como "sistema" educacional brasileiro (Saviani, 2008), ou seja, com pretensão de validade nacional, precisaria articular normativas e práticas como condição de ser considerado, de fato, um "sistema".

Dentre as diversas esferas envolvidas neste cenário, destaca-se o chamado currículo. Sua importância é grifada no título da nova Base e nele se assentam os argumentos para as mudanças, pois ele denuncia a sobrecarga das disciplinas, é questionado com relação ao seu conteúdo, sua importância, sua adequação, sua pertinência. E nele, as atenções se depositam. À revelia de uma discussão mais ampla sobre o próprio conceito de currículo, sobre a infraestrutura das escolas, o investimento financeiro insuficiente, a pouca atratividade de certas carreiras, a explicitação de sua função, o currículo será (está sendo?) alterado. Mas cabe perguntar, mudar como e por quê? O que é desnecessário (errado?) no material que temos em voga há mais de vinte anos desde os discutidos e elogiados PCN (Parâmetros Curriculares Nacionais de 1997)? Mudanças, de fato, ocorrerão ou será apenas um rearranjo de conteúdos (como já ocorrido) em tempos anteriores? Qual será o espaço deste documento diante de um sistema normativo já sólido no campo educacional brasileiro? O propósito de trazer as questões não se deve à intenção de sua resposta neste texto; explica-se: seria uma grande satisfação saber ou conseguir obter essas respostas a 
partir dos documentos e/ou dos trabalhos já publicados acerca do tema, mas isso não é completamente possível, por enquanto. E, devido à impossibilidade, apresenta-se (apenas) um estudo da história e o exercício hermenêutico da compressão compartilhada. Assenta-se aqui a intenção de que, brevemente, sejam conhecidos todos os rumos e os impactos da medida neste texto discutida.

Cientes de todo o cenário mais amplo que sustenta as discussões deste texto, nele é trazida uma discussão sobre o ensino da disciplina de Química na educação básica, tendo-se como suporte os diferentes documentos orientadores do ensino no Brasil, seu currículo, seus modos de fazer. Por meio desta disciplina, buscou-se na história de sua constituição curricular no Brasil, ao longo dos últimos anos, a compreensão de sua função e de sua importância. Além disso, destacou-se a complexidade que tem sido a implementação de um "sistema" que é curricular e que se materializa de diferentes modos, ênfases e valores nas, sempre presentes, demandas da educação brasileira.

\section{Os documentos normativos e suas principais características}

O direito à Educação foi estabelecido como um direito social pela Constituição de 1988, constituindo-se obrigação tanto do Estado, quanto da família. Não obstante a garantia constitucional, também ficou descrito que a "educação proporcionará ao aluno a conscientização e o desenvolvimento do espírito crítico de maneira suficiente ao exercício da cidadania" (Santos, 2008; Alves; Silva; Andrade, 2016; Brasil, 1988). Neste sentido, o artigo 205 da Constituição Federal (Brasil, 1988) descreve "A educação, direito de todos e dever do Estado e da família, (...), visando (...) seu preparo para o exercício da cidadania e sua qualificação para o trabalho" (grifo das autoras).

Quase uma década após a promulgação da Constituição Federal, em 1996 foi publicada a Lei de Diretrizes e Bases da Educação Nacional (Lei 9.394/96, LDB), em cujo teor tornou o Ensino Médio parte integrante da Educação Básica (Alves; Silva; Andrade, 2016), passando, portanto, a possuir características finalistas, de etapa conclusiva da Educação Básica (Brasil, 1996):

Art.35 - O Ensino Médio, etapa final da Educação Básica, com duração mínima de três anos, terá como finalidade:

I - a consolidação e aprofundamento dos conhecimentos adquiridos no ensino fundamental, possibilitando o prosseguimento de estudos;

II - a preparação básica para o trabalho e a cidadania (...);

III - a compreensão dos fundamentos científico-tecnológicos dos processos produtivos, relacionando a teoria com a prática(...). (grifo das autoras)

Com o intuito de cumprir o previsto na LDB, foram instituídos, em 1997, os Parâmetros Curriculares Nacionais (do Ensino Médio), PCNEM, cuja função foi viabilizar a prática docente, a fim de que a mesma pudesse se efetivar em harmonia ao que 
previamente fora estabelecido por esta Lei 9.394/1996 (LDB) (Nunes, 2007; Azanha, 2000).

Posteriormente, em 2000, uma nova versão dos PCNEM foi lançada, sendo estes "constituídos de um caderno com as Bases Legais e outros três, que propõem um ensino concentrado em três grandes áreas: 'Linguagens, Códigos e suas Tecnologias'; 'Ciências da Natureza, Matemática e suas Tecnologias' e 'Ciências Humanas e suas Tecnologias' para favorecer a interdisciplinaridade" (Alves; Silva; Andrade, 2016, p.56), facilitando o trabalho pedagógico articulado em/nas áreas. Ao contrário do que se poderia, a priori, pensar, quando da leitura do termo "parâmetros", o documento em análise não traz em si detalhamento algum sobre os tópicos que se espera sejam ensinados no Ensino Médio, funcionando, de fato, apenas como um eixo central. Inclusive, o referido documento deixa expresso que, posteriormente, outro documento se ocupará de aludido detalhamento (Alves; Silva; Andrade, 2016) - como será discutido nos tópicos seguintes. Preocupou-se, nos PCNEM, em promover a ideia de um Ensino Médio finalista, no qual o aluno tenha conhecimentos suficientes para a compreensão de fenômenos e tecnologia do cotidiano, bem como para o exercício da cidadania, além do fato de que tal Ensino seja útil tanto para aqueles concluintes que prosseguirão os estudos, quanto àqueles cujo destino será o mercado de trabalho e a vida profissional. Apregoa-se, ainda, que almejado Ensino Médio promova a interdisciplinaridade, todavia, sem abandonar a costumeira e conhecida divisão em nível disciplinar, uma vez útil à organização dos conteúdos.

No ano 2002, foram instituídos os PCN+ para o Ensino Médio, cuja finalidade foi complementar os PCNEM. Os PCN+ não apresentaram intenção normativa, mas sim instrutiva e de funcionarem como complementos aos PCNEM - até mesmo porque os próprios PCNEM foram expressos no sentido de preverem que somente um documento futuro se ocuparia em elencar os tópicos que se esperam ser trabalhados no Ensino Médio. Assim, o objetivo do PCN+ consiste em elencar sugestões para as atividades educativas, bem como para a disposição curricular. O texto introdutório dos $\mathrm{PCN}+$ faz menção da necessidade de mudanças do Ensino Médio, uma vez que "destaca que o desinteresse pelo ensino é produto tanto da escola, (ainda) transmissiva - tal como destacam os PCNEM quanto do ensino sem contexto, não só para os alunos, mas, também, para os professores" (Alves; Silva; Andrade, 2016, p.155). Os PCN+ consideram a pluralidade do sistema de ensino no Brasil, razão pela qual deixaram a possibilidade de adequação às particularidades regionais. No entanto, destaca que, mesmo nas escolas em que o número de aulas de determinada disciplina seja reduzido, existem conteúdos que não devem ser descartados. É a chamada "base comum" que a LDB prevê (Brasil, 1996):

Art. $9^{\circ}$ A União incumbir-se-á de: (...) IV - estabelecer, (...), competências e diretrizes para a educação infantil, o ensino fundamental e o ensino médio, que nortearão os currículos e seus conteúdos mínimos, de modo a assegurar formação básica comum; (...) (grifo das autoras) 
Além disso, os PCN+ preconizaram o ensino não atrelado à obrigação de divisão em disciplinas, mas sim fundamentado em temas gerais, capazes de compreender diversas disciplinas e/ou conteúdos. Estes foram denominados Temas Estruturadores, que se constituem uma proposta de organização de conteúdos, considerando-se a vivência individual dos alunos, os quais são: 1. Reconhecimento e caracterização das transformações químicas; 2. Primeiros modelos de constituição da matéria; 3. Energia e transformação química; 4. Aspectos dinâmicos das transformações químicas; 5. Química e Atmosfera; 6. Química e Hidrosfera; 7. Química e Litosfera; 8. Química e Biosfera; 9. Modelos quânticos e as propriedades químicas. Com estes pretende-se a realização de uma mescla de conhecimentos de mais de uma disciplina de uma mesma área e até mesmo interáreas (Both, 2007; Santos, 2008).

Estudiosos da Educação já previam que a "lacuna" deixada pelos PCNEM possibilitaria o surgimento de novas propostas curriculares, a níveis estaduais, municipais e até mesmo escolares (Lopes, 2002, p. 116). E, foi exatamente o que ocorreu no Estado de São Paulo, com a admissão da Proposta Curricular do Estado de São Paulo para a disciplina de Química. De forma contrária à liberdade concedida pelos documentos anteriores, a Proposta Curricular entrou em vigor em 2008, como tentativa de conter a ingerência promovida em face dos documentos prévios ao longo do tempo (São Paulo, 2008. p. 5.): “(...) essa tática descentralizada mostrou-se ineficiente. Por esse motivo, propomos agora uma ação integrada e articulada, cujo objetivo é organizar melhor o sistema educacional de São Paulo". Posteriormente, em 2013, a primeira versão atualizada da Proposta foi publicada. Esta é composta por três documentos, o primeiro contendo princípios norteadores da Proposta; o segundo, voltado aos dirigentes escolares e aos professores e, por fim, os cadernos para os alunos. Em 2019 os Cadernos do aluno (material de apoio aos alunos e professores enviados pela Secretaria Estadual de Educação), foram suspensos e, até este momento, meados de 2020, os professores aguardam uma Nova Proposta Curricular para o Estado de São Paulo e novos materiais de apoio que estão em elaboração.

Em setembro de 2016, por meio da Medida Provisória n 746/2016, o Governo Federal Brasileiro instituiu modificações no currículo do Ensino Médio. Referida Medida Provisória foi convertida em lei em 2017: Lei n ${ }^{\circ}$ 13.415/2017, ampliando a carga horária do Ensino Médio, introduzindo o Ensino Médio integral de forma gradual, etc., alterando, desta maneira, diversos artigos da LDB (Brasil, 2017). Embora já sancionada, a reforma do atual Ensino Médio somente seria colocada em pleno exercício após a aprovação da Base Nacional Comum Curricular (BNCC), prevista desde a aprovação do texto da LDB em 1996. Esta Base foi homologada pela Portaria $\mathrm{n}^{\circ} 1.570$, publicada no D.O.U. de 21/12/2017, Seção 1, Pág. 146, sendo nas primeiras linhas do texto introdutório descrito que se trata de documento de caráter normativo, funcionando como definidor das "aprendizagens essenciais", as quais constituem condições sine qua non à formação dos estudantes (p. 7), embora não sejam equivalentes ao conteúdo mínimo. Pretende-se com tal documento a regulamentação desde a creche, aos anos finais do ensino médio.

Nas primeiras páginas da BNCC, na Apresentação, encontra-se definido que embora se trate de documento destinado à promoção da equidade no ensino, serão preservadas a 
autonomia dos entes federativos, bem como as variações de caráter regional e local (p. 5). Neste sentido, o documento enfatiza que comuns são as aprendizagens essenciais, mas não os currículos. Em seu bojo, são definidas dez competências sobre as quais se desenvolve todo o conteúdo da BNCC. Competências, no contexto da Base, são entendidas como "mobilização de conhecimentos (conceitos e procedimentos), habilidades (práticas, cognitivas e socioemocionais), atitudes e valores" tanto para o cotidiano, quanto o universo do trabalho e o exercício da cidadania (p. 8).

Constituem-se as dez competências, de forma bastante sucinta, resumida sob a ótica das autoras deste texto:

$1^{\text {a: }}$ Valorizar/utilizar os conhecimentos acumulados ao longo da história;

$2^{\mathrm{a}}$ : Exercitar pensamento crítico, inclusive (mas não só) no âmbito científico;

$3^{\text {a: }}$ Valorizar diferentes práticas artísticas e culturais;

$4^{\text {a }}$ : Utilizar diversas linguagens, inclusive as linguagens científicas;

$5^{\mathrm{a}}$ : Compreender/utilizar e criar tecnologias digitais informativas de forma ética e consciente;

$6^{\text {a }}$ : Valorizar a diversidade de saberes e apropriar-se dos conhecimentos relevantes à cidadania, ao trabalho, etc.;

$7^{\mathrm{a}}$ : Argumentar de forma crítica e fundamentada sobre diversos assuntos, como os inerentes ao meio ambiente e ao consumo;

$8^{\mathrm{a}}$ : Conhecer seu corpo e saúde física e mental;

$9^{\text {a }}$ : Exercitar a empatia e o diálogo, promovendo o respeito e a ausência de preconceito;

10a: Agir com autonomia e responsabilidade, fazendo opções fundamentadas em princípios de caráter ético, democrático, etc.

O texto é totalmente perpassado pela ênfase nas competências que o aluno deve ter, não se destacando tanto quais conteúdos serão necessários a fim de que/desde que o mesmo atinja o pleno desenvolvimento dessas competências. Além disso, em diversos pontos da BNCC ficou ora destacado, ora implícito, que a mesma não deve ser confundida com os currículos e que estes seguirão mantidos pelas redes de ensino, tal como já é observado (p.18):

É também da alçada dos entes federados responsáveis pela implementação da BNCC o reconhecimento da experiência curricular existente em seu âmbito de atuação. Nas duas últimas décadas, mais da metade dos Estados e muitos Municípios vêm elaborando currículos para seus respectivos sistemas de ensino, inclusive para atender às especificidades das diferentes modalidades. Muitas escolas públicas e particulares também acumularam experiências de desenvolvimento curricular e de criação de materiais de apoio ao currículo, assim como instituições de ensino superior construíram experiências de consultoria e de apoio técnico ao desenvolvimento curricular. Inventariar e avaliar toda essa experiência pode contribuir para aprender com acertos e erros e incorporar práticas que propiciaram bons resultados. 
Do trecho anterior se pode aferir que não obstante seu caráter normativo, o texto segue assegurando a competência anterior de criação curricular regional e local, tanto dos diferentes entes federativos, quanto das próprias instituições escolares, desde que as esperadas competências sejam promovidas, desenvolvidas.

No que se refere ao Currículo Paulista, as adequações estão ainda em andamento, como pode ser verificado no site da Secretaria da Educação do Estado (https://efape.educacao.sp.gov.br/curriculopaulista/ensino-medio/). Em meados de 2020 foi encerrada uma consulta pública sobre diversos componentes da proposta, como as questões socioemocionais, o conteúdo e a função das disciplinas, os projetos de vida, a educação inclusiva, etc. E, espera-se que em 2021 as mudanças comecem no $1^{\circ}$ ano; em 2022 , no $2^{\circ}$ ano; e em 2023, no $3^{\circ}$ ano. As mudanças são anunciadas como consideráveis e diversas, mas o que chama a atenção é que o termo "estrutura" aparece recorrentemente nos documentos, apontando para uma direção acentuada e rígida no que se refere à organização do Ensino Médio.

\section{Fundamentação teórica}

O Currículo Paulista apresentou à comunidade do estado um questionário para consulta pública que apresentava uma lista de itens referente aos quais a população podia comentar e conferir relevância e pertinência a cada texto apresentado. $\mathrm{Na}$ lista de itens figuravam questões para/sobre a história do ensino médio; a juventude; formação para a vida; projeto de vida; inclusão, educação de jovens e adultos; áreas de conhecimento, componentes curriculares (disciplinas); desenvolvimento socioemocional e desenvolvimento intencional de competências socioemocionais; organizador curricular com: competências, habilidades, unidade temática e objetos de conhecimento. E, ao mencionar esses termos chama-se atenção para o fato de que o Currículo como lista de conteúdos de uma disciplina distanciase desse novo formato, no qual a vida, o futuro, a postura, as emoções e a leitura do mundo passam a figurar como partes essenciais que descrevem o currículo como tudo que caracteriza a vivência humana durante um período de tempo no espaço escolar.

O presente item inicia-se com esta descrição do Currículo do Estado de São Paulo com o intuito de reconhecer que a história do currículo passou por diferentes fases e ênfases e, aqui no ano de 2020, a proposta apresentada pelo estado parece buscar abarcar essa historicidade reconhecendo que a materialidade do currículo, de fato, só ocorre no seu acontecimento em sala de aula. Sem fazer uma fundamentação teórica exaustiva busca-se apenas sumarizar alguns elementos reconhecendo que a complexidade do assunto é bem maior.

$\mathrm{Na}$ literatura não é incomum identificar-se que o Currículo é descrito com diferentes significados, mas costuma se referir, no comum dos sensos, às disciplinas, ao conteúdo e ao conjunto de valores que são, de alguma forma, "transmitidos" e construídos pela Escola. Essa definição é característica de uma compreensão mais tradicional de currículo. Criada como reflexo do "sucesso" da revolução industrial, o currículo tradicional, iniciado nos 
Estados Unidos e comumente atribuído a Bobbit, tinha sua base no modelo econômico de Frederick Taylor (Hornburg; Silva, 2007). Ou seja, pensava-se a escola como um local de formação para o mundo do trabalho, controlado, aferido e com forte ênfase na aprendizagem de habilidades individuais. De acordo com Hornburg e Silva (2007), outra proposta, referenciada a John Dewey, era considerada mais progressista, mas ainda assim tradicional, preconizava que o ensino considerasse a experiência individual e que a estrutura e a forma atentassem para os preceitos da democracia liberal. Para Pacheco (2011, p. 77), em todo o processo de formação educacional “[...] o currículo adquire centralidade, pois não só é conhecimento, como também é um processo que adquire forma e sentido, de acordo com a organização em que se realiza e em função do espaço e tempo em que se materializa." Além disso, os conceitos de currículo abarcam também os aspectos normativos que, segundo Young $(2014$, p. 05) podem se referir a dois aspectos: um deles seria o conjunto de "[...] regras (ou normas) que orientam a elaboração e a prática do currículo; o outro se refere ao fato de que a educação sempre implica valores morais sobre uma boa pessoa e uma "boa sociedade" - em outras palavras, para que estamos educando?"

Como um movimento contrário, surgem na década de 1960 as chamadas teorias críticas do currículo. Proposições de Althusser enfatizam a importância da escola como reprodutora de um certo modelo de sociedade, mas além dele diversos autores da segunda metade do século XX questionam os motivos da estrutura e dos conteúdos que compõem a escola contemporânea (Silva, 1999). De modo ainda mais questionador, Bourdieu e Passeron (1992) apontam para a necessidade de se considerar que a escola, de diferentes modos e ao conferir veracidade e valor, consolida uma cultura dominante, não apenas por descrever certos conteúdos, mas por impedir que certos grupos sociais tenham acesso ao que outros grupos têm.

A partir do reconhecimento do papel da cultura na determinação de valores dentro da escola, surge um movimento chamado de pós-crítico. Ou seja, para além da crítica ao modelo que privilegia grupos específicos há que se reconhecer que certos elementos precisam figurar no panorama curricular e organizacional da escola para que, de fato, se avance na superação do simples reconhecimento das diferenças. O currículo multicultural, ou multiculturalista visa contemplar questões da diferença cultural com base em discussões sobre aspectos que envolvem as minorias e os mais diversos grupos sociais, para além dos conteúdos tradicionais (Hornburg; Silva, 2007).

Por considerar que ambas as esferas do currículo (normativa e de valores morais) podem ser estudadas por meio dos conteúdos e das habilidades a eles articulados, é que o presente trabalho objetiva entender, via diferentes documentos oficiais, como este currículo é descrito como forma de funcionamento do processo educacional. Como maneira de circunscrição, apresentam-se as modificações do currículo de química do ensino médio nos últimos vinte anos, por meio dos documentos orientadores do ensino no Brasil, desde a LDB até a nova Base Nacional Comum Curricular (BNCC). 


\section{Metodologia}

O trabalho corresponde aos moldes de uma pesquisa qualitativa documental, pois tem como base de estudos documentos relativos às normatizações e regulamentações educacionais em nível federal e estadual e a abordagem de análise adotada preza pela interpretação hermenêutica de seu conteúdo. Segundo Ludke (1986), qualquer material escrito, tal como leis e regulamentos, normas e pareceres, pode ser considerado como documento e, nesta investigação, partiu-se da leitura e análise dos documentos orientadores do ensino, quais sejam, PCNEM, PCN+, Proposta Curricular do Estado de São Paulo para a Disciplina Química e a BNCC, com intuito de identificar pontos de convergência e divergência que tivessem como esfera as habilidades e competências para uma área específica do conhecimento, o ensino da Química. Neste sentido, os significados, motivos, aspirações e crenças buscados nesta análise têm como foco a identificação de relações discursivas dos processos e dos fenômenos que não podem ser reduzidos à operacionalização de variáveis (Minayo, 2014).

Como forma de criação e organização do objeto de investigação foram utilizados dois recursos: a leitura e análise exploratória dos textos e, além disso, para facilitar a visualização na apresentação dos resultados, foi utilizado o recurso de um software para elaboração de word clouds (nuvem de palavras), com ênfase para as palavras que tiveram maior índice de repetição em cada documento. Segundo Lemos (2016, p. 13) "As nuvens são, portanto, a representação de uma lista hierarquizada visualmente, com fins de classificação, em que a quantidade maior ou menor de aparições de determinado termo é dada proporcionalmente pelo tamanho da fonte." A utilização deste recurso visa, portanto, apresentar um primeiro contato com o conteúdo em análise e "[...] atende a necessidade de identificar quais termos são mais discorridos e utilizados ao se debater sobre um tema [...]" (Melo; Vasconcelos-Silva, 2018).

Na busca de superar as barreiras da padronização e quantificação (Bogdan, 1994), buscou-se analisar se as palavras se repetiam e se havia semelhanças nas habilidades $e$ competências e também na parte de conteúdos anunciados nos diferentes documentos. Nesse sentido, o estudo buscou analisar se havia mudanças substanciais considerando que, historicamente, a etapa do Ensino Médio vem passando por reformulações que nem sempre repercutem em alteração no campo prático de trabalho em sala de aula. As nuvens de palavras foram geradas utilizando-se o site "www.wordclouds.com", retirando-se das listas de palavras - originais dos textos dos documentos oficiais - apenas os verbos no gerúndio, as conjunções, os artigos definidos e indefinidos, as preposições, os pronomes relativos, os advérbios e demais conectores.

Todos os documentos mencionados foram analisados em sua integralidade, buscandose extrair tanto o sentido geral trazido/pretendido por cada um deles, quanto as particularidades apresentadas: seu caráter como (apenas) direcionador/norteador do ensino, ou impositivo, sua menor ou maior amplitude, sua ênfase conteudista (ou não), a divisão em disciplinas (ou não), bem como os conteúdos específicos, etc. As observações estão expostas de forma direcionada para o tema abordado neste artigo e, principalmente, foram 
trazidos à tona os aspectos com possibilidade de análise comparativamente com a nova BNCC - no sentido de considerar as mudanças ou manutenções nas abordagens, em relação aos documentos anteriores.

Como já delineado nas páginas antecedentes, os documentos possuem rigidez, estruturação, e previsões distintas, razão pela qual apenas alguns recortes, passíveis de comparação, constituíram os resultados apresentados visualmente na forma de word clouds, os quais foram obtidos com: as competências e habilidades previstas para o Ensino Médio, na Disciplina Química, nos PCNEM; as competências, na Disciplina Química, nos PCN+; os conteúdos específicos previstos para o Ensino Médio, na Disciplina Química, na Proposta Curricular do Estado de São Paulo; e, no caso da BNCC, as habilidades previstas para o Ensino Médio, na área de Ciências da Natureza e suas Tecnologias.

\section{Resultados e Discussão}

Com relação aos PCNEM, por se tratar de trabalho cujo tema é atinente ao Ensino de Química, a análise deu-se somente na segunda grande área, com enfoque na parte concernente à Química. Sobre esta disciplina, os PCNEM criticam o atual ensino, destacando o fato de que apesar do enorme avanço científico-tecnológico nos últimos quarenta anos, o Ensino de Química não mudou: ocorre, ainda, com ênfase nas informações que não fazem mais parte da vivência dos alunos e, nem mesmo dos professores. Outro aspecto nítido quando da análise dos PCNEM é que a linguagem química não deve consistir no fim em si mesma, mas apenas servir como meio, como ferramenta que subsidie o ensino desta ciência.

No primeiro momento do Ensino Médio, os PCNEM preveem a abordagem de transformações químicas, inicialmente de maneira qualitativa. $\mathrm{O}$ documento sugere que os conceitos sejam tratados a partir de fatos, da realidade, do cotidiano dos alunos. Sem se esquivar da proposta inicial, em um segundo momento, sugerem sejam trazidas informações sobre a vivência do ser humano, traduzidos em estudos sobre a biosfera, a atmosfera, a litosfera e a hidrosfera. Os PCNEM preveem explicitamente a experimentação. Sobre este assunto, destaca-se a necessidade de que a mesma ocorra com caráter pedagógico: "A experimentação, que na escola tem função pedagógica, diferentemente da experiência conduzida pelo cientista - teoria e prática não se desvinculam (...)" (Brasil, 2000, p. 36).

Como competências e habilidades a serem desenvolvidas destacam-se, no que concerne à Representação e Comunicação, o uso de linguagens químicas, códigos, símbolos, etc. No que se refere à Investigação e Compreensão, destacam o ensino de conceitos em visão macroscópica, resolução de problemas e previsões sobre as transformações químicas. No que concerne à Contextualização Sociocultural, pretende-se que o aluno consiga perceber os aspectos químicos no meio em que vive.

Enfim, os PCNEM expressam o conteúdo químico de maneira bastante genérica, sendo nítido que focam mais as competências e habilidades a serem desenvolvidas no aluno do 
que os conteúdos propriamente ditos, objetivando-se a preparação para a vida e para o exercício da cidadania. Os exemplos possuem mais caráter metodológico do que de conteúdo: "A reforma pretendida transcende a mera alteração de conteúdos a ensinar, mas tem a dimensão mais ampla de desenvolver as várias qualidades humanas; (...) não só os conteúdos a ensinar, mas (...) qual aluno se quer formar".

Assim, o conteúdo geral prenunciado nos PCNEM torna-os passíveis de "se adequarem a diferentes grupos, realidades, distribuídos por todo o território brasileiro" (Alves; Silva; Andrade, 2016, p. 156). Neste caso, a contextualização é mormente associada à necessidade de que o aluno deixe de assumir a função de espectador, para que possa sentir-se inserido no contexto que lhe é ensinado na escola (Lopes, 2002). Por fim, nota-se que foi mantida a autonomia da escola garantida pelo artigo 12 da LDB.

Os PCN+, por sua vez, propagam uma disciplina de Química desenvolvida sobre o tripé "transformações químicas; materiais e suas propriedades e modelos explicativos", para sobre este tripé se concretizar o desenvolvimento cognitivo dos alunos, bem como de todas as competências e habilidades que são "esperadas" para este nível do ensino no Brasil e são trazidos pelo documento em comento (Brasil, 2002, p. 10). A proposta dos PCN+ é, inicialmente, fazer com que o aluno entenda a Química dos recursos disponíveis na Terra, para, posteriormente, compreender como o homem utiliza estes recursos e sintetiza os materiais necessários à sua vida.

Uma vez discutido o texto introdutório, passa-se à análise do conteúdo específico de Química a que referido documento faz alusão. Com relação às competências que devem ser desenvolvidas, serão destacadas aquelas julgadas como sendo as que os PCN+ atribuíram maior ênfase. No que tange ao desenvolvimento das capacidades de Representação e Comunicação dos alunos, pretende-se que consigam reconhecer e compreender símbolos, nomenclatura química, entender linguagens variadas nas quais os dados de um problema químico muitas vezes se acham permeados, bem como em textos. Além disso, se espera que aprendam consultar diferentes fontes informativas; entender e "desvendar" mitos do conhecimento e do senso comum. E, por fim, que consigam descrever informações sobre eventos da sua vida, eventos de cunho químico, em linguagem química.

No que se refere ao desenvolvimento das capacidades de Investigação e Compreensão dos alunos, é pretendido que o Ensino de Química o seja de modo a propiciar que os alunos consigam achar uma "solução química" para uma situação problema do seu cotidiano, entendam conceitos e a relação entre matéria e energia, além de identificarem transformações químicas e saberem fazer previsões e estimativas quanto a essas transformações. Espera-se que aprenda o uso de diferentes escalas de unidades de medidas e, ainda, entendam o funcionamento e fundamento de diversos modelos tanto macro quanto microscópicos, inclusive, suas limitações. Por fim, se espera que os alunos consigam relacionar a Química com outras ciências e fazer relações entre as áreas da própria Química.

E, no que alude ao desenvolvimento da Contextualização Sociocultural, almeja-se que o aluno consiga entender o lugar da Química na história e no desenvolvimento da tecnologia, inclusive atual. Assim como a relacionar com o ambiente em que vive e com as 
responsabilidades sociais decorrentes da apropriação desse conhecimento e com a própria ética (Brasil, 2002).

O documento é dividido por temas estruturadores e, de um modo geral, até o quarto tema estruturador (Aspectos dinâmicos das transformações químicas) enfatiza-se o Ensino de Química Geral, com enfoque inorgânico e físico-químico. A partir do quinto tema estruturador, passa-se a ter um enfoque ambiental, porém sem ênfase em Química Orgânica. Na sequência dos temas estruturadores são apresentadas algumas propostas de sequências didáticas que sugerem quando/em qual fase do decorrer do Ensino Médio podem ser abordados os temas. As propostas foram elaboradas tanto para escolas que possuem elevado número de aulas de Química, quanto para escolas com menor número de aulas.

Da análise da Proposta Curricular do Estado de São Paulo é possível verificar que se pretende um ensino voltado à compreensão de processos químicos correlatos às aplicações de cunho ambiental, social, político, econômico e tecnológico, para que o aluno, como cidadão, possa emitir juízos de valor de maneira consciente das consequências advindas destas decisões. Propõe, à maneira do que é feito pelos PCNEM, mudança no ensino habituado à memorização, à classificação, bem como às fórmulas e às equações, além de manter o estudo sobre o tripé "transformações químicas, materiais e suas propriedades e modelos explicativos" (São Paulo, 2008, p. 42; Brasil, 2002, p. 116).

Tal proposta posiciona-se de maneira contrária à aceitação do ensino que parte do universo microscópico, haja vista a necessidade de um grau maior de abstração do aluno e, o aluno que não possui contato algum com a Química, não conhece sequer os fatos químicos (São Paulo, 2008). Assim, se promoveu ao longo de todo o documento um posicionamento que implica em respeito ao "nível cognitivo do aluno", começando do universo macroscópico para possibilitar o desenvolvimento cognitivo e, somente em momento subsequente, o universo microscópico (São Paulo, 2008, p. 43).

De modo sucinto, a Proposta Curricular do Estado de São Paulo propõe para o primeiro ano conteúdo envolvendo as transformações químicas, desde aspectos qualitativos a quantitativos, inclusive abordando estequiometria; métodos de separação; modelo atômico de Dalton e extração de alguns metais. Para o segundo ano, propõe o tratamento de água; medidas da quantidade de oxigênio na água; concentrações; modelo atômico de Rutherford e Bohr, relacionados com as propriedades da Tabela Periódica; termoquímica e eletroquímica relacionadas às ligações químicas (rompimentos e formações das ligações); interações entre as partículas e os resultados da alteração de temperatura, pressão e outros parâmetros, nos estados sólido, líquido e gasoso. Por fim, para o terceiro ano, está previsto o ensino, agora mais aprofundado, de técnicas de separação de misturas; equilíbrio químico; composição dos alimentos; fontes alternativas de combustíveis (biomassa); modelos explicativos para o átomo de carbono e suas peculiaridades (cadeias, ramificações, etc.); materiais orgânicos: petróleo, gás natural; carvão mineral. Por fím, finaliza retornando à Química Inorgânica - visto que praticamente todo o conteúdo versado nesta série se refere à Química Orgânica - abordando os ciclos do nitrogênio e da água e a poluição causada, principalmente, por óxidos. 
Após a análise prévia dos três documentos, dois nacionais e um estadual, orienta-se a discussão para o documento de ordem nacional (BNCC) homologado no final de 2018. Trata-se de documento que abarca funções semelhantes àquelas trazidas pelos anteriormente apresentados, porém com peculiaridades que serão a partir deste ponto consideradas. Pretendendo unificar o ensino desde a creche aos anos finais do ensino médio no país, a BNCC possui caráter normativo, definindo o que passa a ser considerado essencial na formação dos alunos, mas ressalta a autonomia para a produção e promoção dos currículos pelos entes federativos do país.

A nova BNCC modificou sobremaneira a anterior concepção de fragmentação dos assuntos em disciplinas (Brasil, 2017), seguindo a tendência há anos instaurada no ENEM e, atualmente, em cenário em diversos vestibulares de grande impacto no país (Brasil, 2017). Neste sentido, as disciplinas de Química, Física e Biologia aparecem unidas em um único bloco, denominado "Ciências da Natureza e suas tecnologias", acompanhando o modelo existente no Ensino Fundamental. Não obstante esta nova configuração, é expresso que a manutenção em disciplinas individualizadas é facultada, sendo que esta nova configuração "não exclui necessariamente as disciplinas" cabendo aos professores a contextualização e manutenção de relações entre elas (p. 469), muito embora o documento carregue a posterior afirmação de que é necessário "romper com a centralidade das disciplinas nos currículos e substituí-las por aspectos mais globalizadores (...)" (p. 471), apresentando, ato contínuo, algumas sugestões de rompimento com a centralidade imposta pelas disciplinas: tais como oficinas, laboratórios, núcleos de estudos, etc.

Para o Ensino Médio, é previsto, em linhas gerais, o ensino de quatro áreas: "Linguagens e suas Tecnologias, Matemáticas e suas Tecnologias, Ciências da Natureza e suas Tecnologias, Ciências Humanas e Sociais Aplicadas" (p. 32). Em virtude da apresentação conjunta dos conteúdos, imprescindível analisar a área de Ciências e Tecnologias como um todo, em cujo teor está prevista a utilização dos conteúdos (já apresentados no Ensino Fundamental) para argumentar e propor soluções referentes à vida e ao meio ambiente.

Propõe, para tanto, um aprofundamento das temáticas abordadas no Ensino Fundamental: matéria e energia, vida e evolução, Terra e Universo. Neste sentido, propõem-se abordagens de conceitos mais abstratos e conteúdos de cunho mais quantitativo em relação àqueles previstos para o Ensino Fundamental, além de maior exploração de modelos explicativos e assuntos mais complexos relacionados às tecnologias. Especificamente, são previstas competências para esta área do conhecimento, as quais sucintamente consistem em: saber analisar os fenômenos naturais e os processos tecnológicos, a fim de aplicar o conhecimento em ações relacionadas ao meio ambiente e de condições de vida; conseguir interpretar a vida, a Terra e o Universo; interpretar problemas referentes ao conhecimento científico e tecnológico.

Sem a intenção de esgotar os reflexos no ensino e na sociedade que a BNCC implicará - embora importante destacar que discussões defendendo um ensino menos fragmentado por disciplinas e mais integrado têm ganhado força na sociedade atual (Lopes; de Abreu, 2010), pretende-se comparar o quanto os conteúdos foram modificados, em relação aos 
documentos anteriores. Para tanto, far-se-á uso de word clouds - recurso digital que possibilita por meio de esquemas comparar a incidência de palavras em determinado conteúdo textual (Prais; Rosa, 2018) - de modo a viabilizar a interpretação do enfoque pretendido por determinado documento/texto.

\section{Estudo comparativo entre os diferentes documentos}

Comparada com os antigos documentos regulamentadores do ensino, a atual BNCC propõe um ensino menos fragmentado, menos conteudista e nitidamente mais preocupado com o desenvolvimento de habilidades do aluno, via das já comentadas competências (Brasil, 2017).

Neste sentido, embora em seu texto a BNCC explicite que ela, per si, não se constitui como um "novo currículo", atribuindo essa função às unidades escolares e aos entes federativos, sob a ótica de concepções mais amplas de currículo, tais como a defendida por Pacheco (2011, p. 77) - para o qual o currículo consiste em todo o conjunto educacional, sendo "processo que adquire forma e sentido" - a nova BNCC traz em seu bojo a constituição de uma nova abordagem curricular em todo o território nacional. Segundo Young (2014), os aspectos que envolvem o currículo, são não somente o bloco de regras e conteúdos, mas toda a implicação de valores morais pretendida, assim notoriamente há uma mudança curricular com este novo documento normativo, BNCC, conforme é possível se verificar pela comparação com os anteriores documentos orientadores do ensino no Brasil, que poderão ser visualizadas nas word clouds posteriormente mostradas.

Quando a BNCC é comparada com os PCNEM de 2000, apenas a parte destinada às competências e habilidades se assemelha, pois o conteúdo foi apresentado de forma totalmente diversa. Isso em razão de, no documento atual (BNCC), os temas aparecerem mesclados e poderem ser desenvolvidos em qualquer ano do Ensino Médio, dentro das competências específicas previstas para a área de Ciências da Natureza e suas Tecnologias, enquanto nos PCNEM é trazida longa relação de conteúdos, inclusive sendo indicada a ordem na qual devem ser trabalhados - embora estes possuam mais caráter metodológico do que de conteúdo e também se note a ênfase nas competências e habilidades a serem desenvolvidas no alunado, focando na preparação para a vida e para a cidadania (Brasil, 2000).

Nos PCNEM, para os anos iniciais do Ensino Médio, indica-se a contextualização e utilização dos conhecimentos prévios dos alunos, priorizando-se a abordagem do universo macroscópico em detrimento do microscópico, iniciando-se com a abordagem de transformações químicas primeiramente de maneira qualitativa, bem como o ensino de temperatura, energia das transformações, massa, tempo, concentrações, catalisadores e depois as transformações de maneira quantitativa, tal como abordado em conteúdo sobre cálculo de velocidade. Os PCNEM sugerem que os conceitos sejam tratados a partir de fatos do cotidiano dos alunos e, sobre este aspecto, os PCNEM apontam para uma visão curricular que se aproxima daquela trazida por John Dewey, a qual embora tradicional, leva 
em consideração, no ensino, a experiência individual do aluno (Hornburg; Silva , 2007). Posteriormente, são previstos os estudos sobre a biosfera, a atmosfera, a litosfera e a hidrosfera (Brasil, 2000). Como competências e habilidades a serem desenvolvidas destacam-se, no que concerne à Representação e Comunicação o uso de linguagens químicas, códigos, símbolos, o entendimento de tabelas, gráficos e relações matemáticas, a aprendizagem da busca de informações. No que se refere à Investigação e Compreensão: o ensino de conceitos em visão macroscópica, de modo a compreender fatos e dados, saber resolver problemas e fazer previsões sobre as transformações químicas. No que concerne à Contextualização Sociocultural: pretende-se que o aluno consiga perceber os aspectos químicos no meio ambiente, em indústrias, no sistema produtivo e rural, no universo tecnológico e até mesmo que consiga ser consciente para discutir os limites éticos e morais do desenvolvimento da ciência.

Os PCNEM não se ocupam em compartimentar a Química, optando por um ensino articulado, em cujo transcorrer se aborde o conteúdo de todas as áreas, mas, sem as subdividir. Também expressam o conteúdo químico de maneira bastante genérica, enfatizando mais as competências e habilidades a serem desenvolvidas no alunado que os conteúdos propriamente ditos, focalizando na preparação para a vida e para a cidadania notadamente, neste ponto, se distanciando da visão tradicional do currículo, em que o mesmo era projetado com vistas ao mercado de trabalho (Hornburg; Silva, 2007). Os exemplos, por sua vez, possuem mais caráter metodológico do que de conteúdo (Brasil, 2000).

Nas figuras a seguir, de forma qualitativa pode-se evidenciar a incidência das palavras nos documentos orientadores do ensino. Nota-se que a BNCC, ao agrupar as três ciências da natureza em um único tópico reduziu bastante a ênfase nas competências e habilidades da química, quando comparada aos PNCEM. Na figura 1 é apresentada a word cloud extraída da BNCC; na figura 2, dos PCNEM; na figura 3, dos PCN+; e na figura 4, da Proposta Curricular do Estado de São Paulo: 
Figura 1. World Cloud contendo as habilidades previstas para o Ensino Médio, na área de Ciências da Natureza e suas Tecnologias, na BNCC.

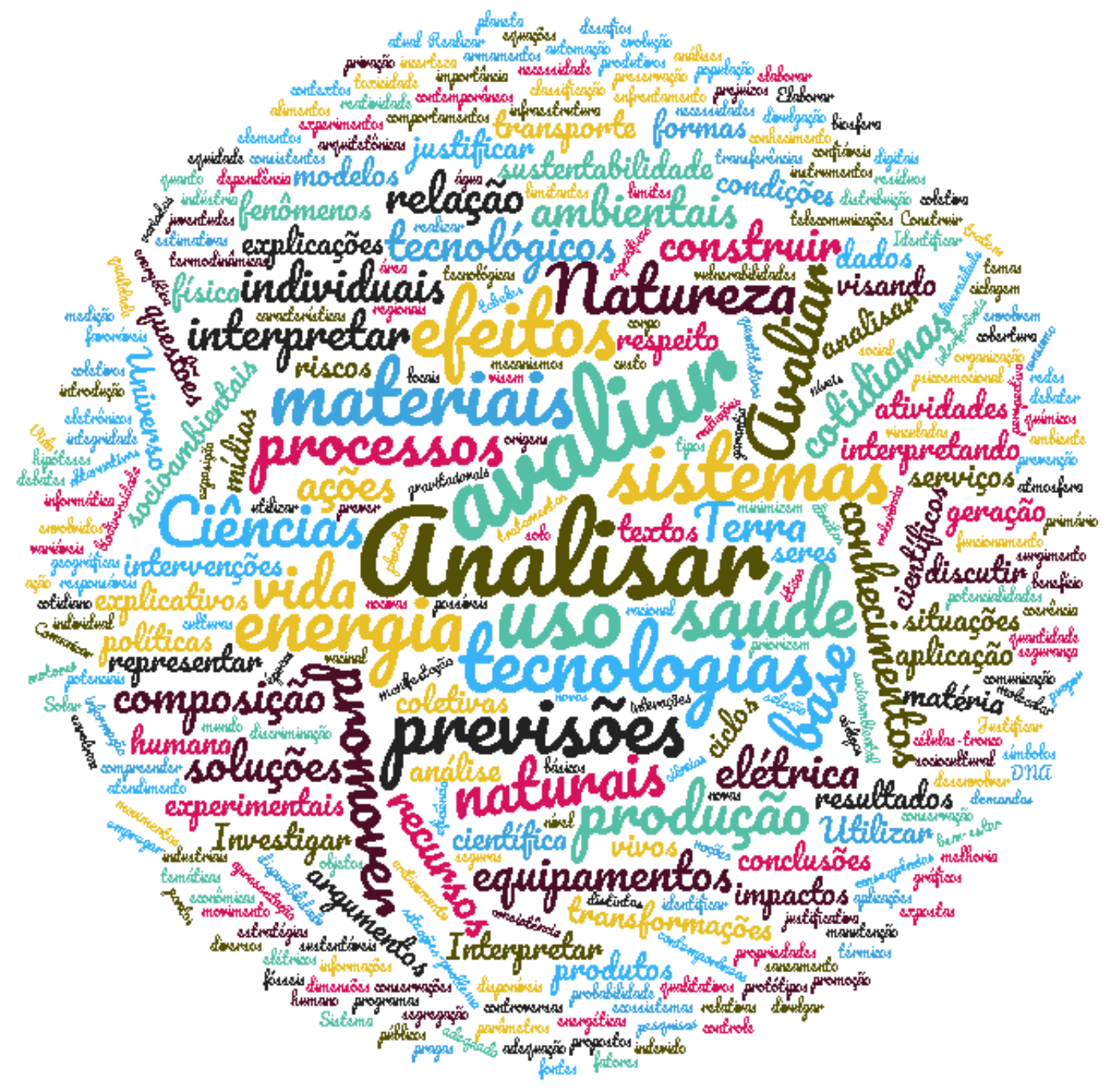

É possível verificar poucas palavras com ênfase que remetem aos conteúdos químicos na world cloud anterior (figura 1), sendo possível identificar, entre outras, as palavras "fenômenos", "materiais", "composição", enquanto maior ênfase é notada para os conteúdos de cunho biológico, referente aos quais é possível verificar, entre outras palavras, as seguintes: "saúde", "natureza", "vida", "vivos", "ambientais", "sustentabilidade", "biodiversidade", "sustentáveis", "células-tronco", DNA, etc. A tendência observada para o ensino de química - de menor ênfase - é acompanhada no caso do ensino de física, referente ao qual se pode observar também menor quantidade de palavras (quando comparada àquela observada para a área de biologia), tais como "elétrica", "física", "térmicos", "telecomunicações". Desta análise é possível afirmar que ao 
priorizar conteúdos biológicos, viabilizou-se o desejado nas sétima e oitava competências trazidas no início da BNCC, que incluem argumentar de forma crítica e fundamentada sobre diversos assuntos, como os inerentes ao meio ambiente e ao consumo e conhecer seu corpo e saúde física e mental, respectivamente (Brasil, 2017).

A seguir, a figura 2 mostra a world cloud para a Disciplina Química, nos PCNEM:

Figura 2. World Cloud contendo as competências e habilidades previstas para o Ensino Médio, na Disciplina Química, nos PCNEM.

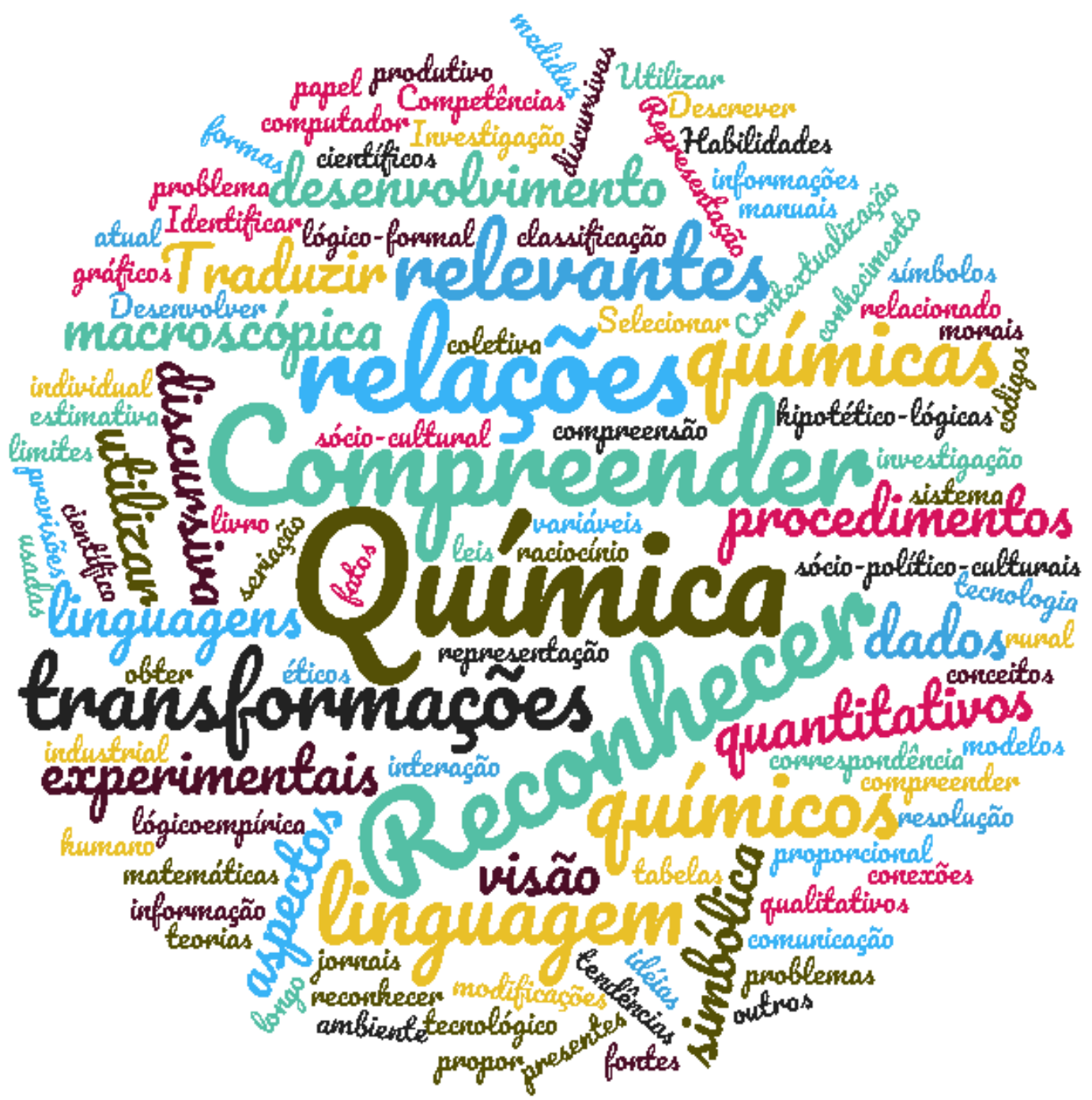

Em relação ao observado na figura 2, conforme mencionado anteriormente, considerando-se a existente separação por disciplina, as palavras que aparecem em destaque na word cloud dos PCNEM são totalmente relacionadas à Química, sendo possível observar ênfase não somente nos conteúdos, mas também na forma como esse conteúdo se 
desenvolve, com destaque para as transformações químicas, os aspectos quali e quantitativos, bem como a própria simbologia e linguagens inerentes à ciência em comento. Trata-se, portanto, em comparação com a nova Base, de documento com caráter mais conteudista, mais afeito à visão de currículo como conjunto de "regras (ou normas) que orientam a elaboração e a prática do currículo" (Young, 2014, p. 05).

Por sua vez, os PCN+ são orientações visando nove temas estruturadores (já apresentados no início deste texto), a fim de serem atingidas as competências e habilidades esperadas, as quais seguem esquematizadas na figura a seguir (figura 3):

Figura 1. World Cloud contendo as competências, na Disciplina Química, nos PCN+.

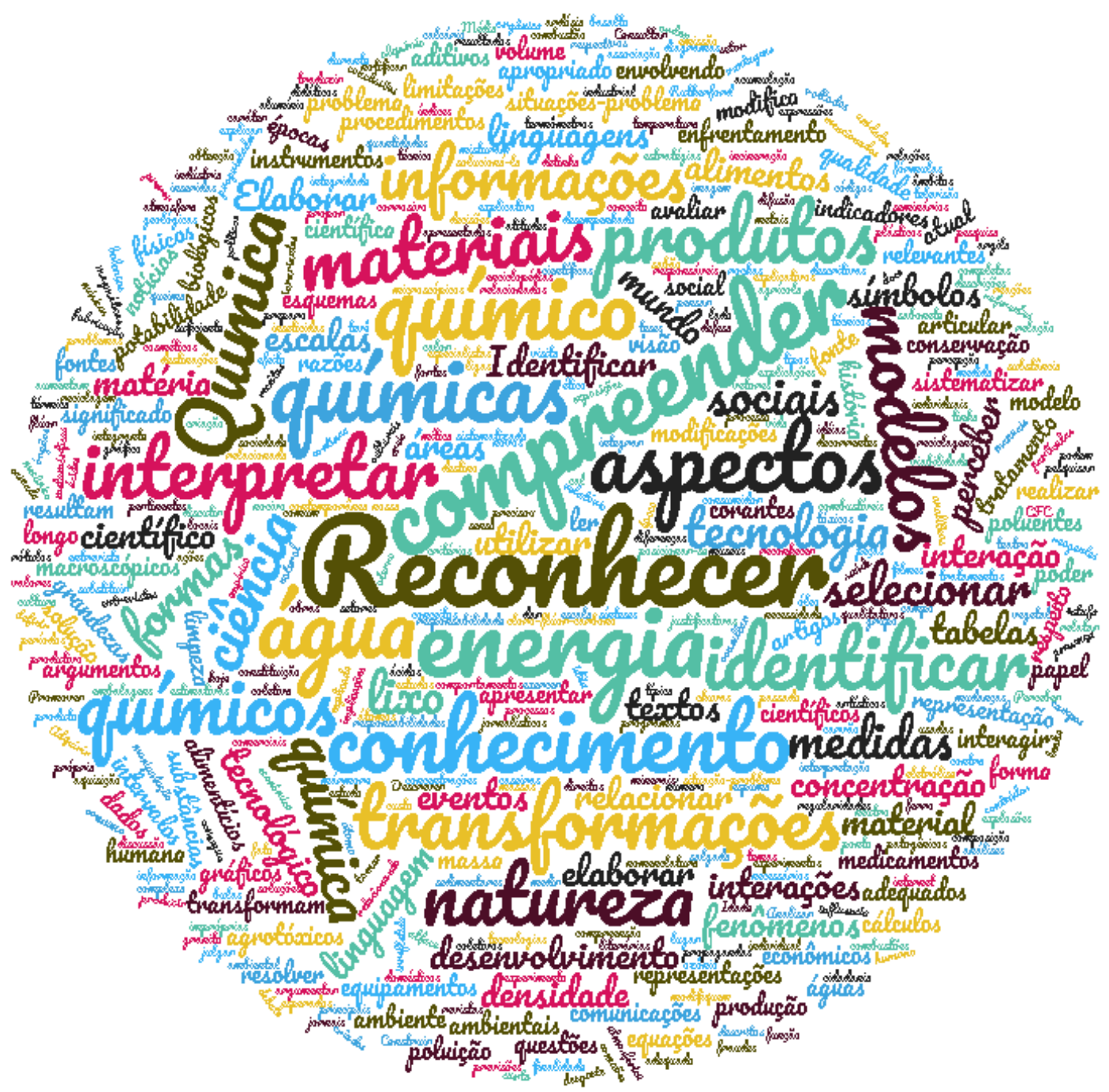


Da figura 3, que se refere aos $\mathrm{PCN}+$, pode-se evidenciar que as competências enfatizam o conteúdo químico direcionado para as aplicações do cotidiano - comprova-se tal fato quando se verifica que a palavra com maior ênfase no texto é "reconhecer", novamente trazendo à tona uma concepção de currículo que embora com certos traços tradicionais, enfatiza a preocupação do conteúdo com "utilidade" para o aluno. No entanto, enquanto esse documento enfatizava, ainda, a utilização de símbolos, a linguagem química, processos e transformações químicas em geral, a BNCC volta-se totalmente ao ensino aplicado: a química voltada aos processos biológicos, geológicos, medicinais, etc., reduzindo a ênfase na aplicação da linguagem química, seus símbolos, etc. No documento anterior $(\mathrm{PCN}+)$ a aplicação/contextualização é trazida a título exemplificativo, enquanto no atual, BNCC, como ênfase e centro do conteúdo.

Das observações precedentes, pode-se aferir que, não obstante a BNCC apresentar como quarta competência pretendida a utilização de diversas linguagens, inclusive as linguagens científicas, quando comparada ao documento anterior, $\mathrm{PCN}+$, a mesma apresentou redução de enfoque na linguagem química (Brasil, 2002; Brasil, 2017) - o que, embora se apresente com caráter de nuances contraditórias, vai ao encontro da proposta de currículo que se afasta das concepções curriculares tradicionais, se aproximando das tendências mais "modernas", críticas e pós-críticas do currículo, haja vista a construção mais ampla e com menor enfoque no tecnicismo, no regramento e no exclusivo preparo para o mercado de trabalho (Young, 2014; Hornburg; Silva, 2007; Silva; Alves; Andrade, 2019).

Ademais, embora tracejado em linhas mais gerais, no sentido de a Química constituir parte de um todo, Ciências da Natureza e suas Tecnologias, o ensino com caráter exemplificativo e aplicado tem se destacado na BNCC, seguindo tendências observadas mundialmente, haja vista que a demanda trazida pela "sociedade do conhecimento" é de um conhecimento mais célere, não raramente dividido e apresentado de forma modular, e com vistas mais superficiais e aplicações direcionadas: “(...) o novo paradigma, (...), reformula o conceito de aprendizagem, que deixa de ser lenta e profunda e passa a ser apressada, fazendo com que os professores e formadores se tornem em meros funcionários do acto pedagógico que acontece na sala de aula" (Pacheco, 2011).

Ainda que seguindo tendências decorrentes da própria globalização, é importante salientar o cuidado na consequente reformulação dos currículos sobre os fundamentos trazidos pela BNCC, uma vez que principalmente na disciplina de Química - ensinada e estudada sob diversos modelos - em alguns conceitos e temas "a descontextualização possibilita que um estudante conheça como se dá a produção de modelos ou fórmulas e reconheça a estrutura do objeto (...) com o qual está trabalhando", tal como afirmam Luccas e Batista (2011) para o ensino de Matemática, a fim de que o ensino não ocorra somente com caráter exemplificativo e sem qualquer capacidade de abstração e compreensão de modelos e fórmulas. Isso porque ainda que se pretenda um ensino mais aplicado, é imperioso reconhecer que disciplinas como a Química necessitam que sejam desenvolvidas algumas habilidades de abstração, até mesmo para a compreensão. 
Em se tratando do Estado de São Paulo, mudança vultosa é notada, haja vista o fato de neste estado existir a Proposta Curricular para o Ensino Médio - proposta esta, conforme já apresentado, rígida e conteudista. A ênfase nos conteúdos de caráter químico e a rigidez da sua abordagem pode ser observada quando os conteúdos, além da previsão das séries, fazem alusão também ao bimestre no qual devem ser ensinados (São Paulo, 2008). É possível verificar na figura 4, a seguir, o caráter com menor ênfase na metodologia, competências e habilidades e maior no conteúdo, em sentido totalmente oposto ao observado na nova BNCC.

Figura 2. World Cloud contendo os conteúdos específicos previstos para o Ensino Médio, na Disciplina Química, na Proposta Curricular do Estado de São Paulo.

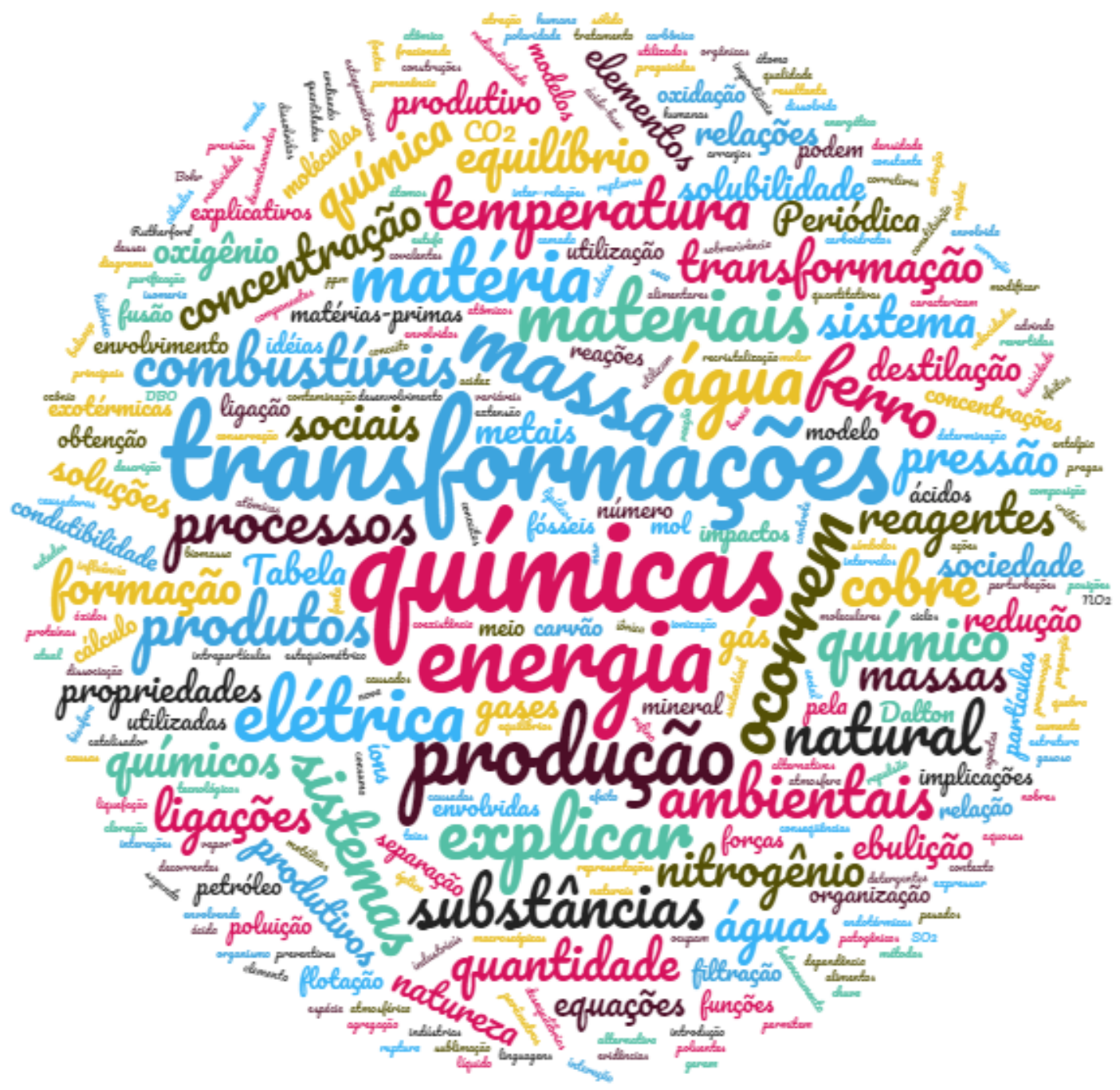


Na word cloud (figura 4), é possível notar que o documento proposto no Estado de São Paulo tem caráter conteudista, sendo possível verificar toda sorte de conteúdos químicos, com maior destaque para "transformações", "energia", "combustíveis", "materiais", "massa", metais como "ferro" e "cobre", mas chegando até funções como "ácidos", processos de separação como "filtração", "flotação" e "destilação", até combustíveis "fósseis".

Assim, a nova BNCC, quando comparada à Proposta do Estado de São Paulo, além de reduzir as exigências relativas ao conteúdo, pode-se afirmar que se trata de um texto menos rígido, o qual, portanto, possibilita que as escolas, bem como os professores - no âmbito dos seus próprios Projeto Político Pedagógico e Planejamento, respectivamente - possam direcionar mais especificamente ao seu público e tenham maior flexibilidade no Planejamento. Trata-se, portanto, - exclusivamente quando postos em posição de comparação - da transição de um modelo de currículo mais tradicional, para um com características daqueles inerentes às teorias críticas e pós-críticas do currículo (Young, 2014; Galian; Louzano, 2014; Hornburg; Silva, 2007; Silva; Alves; Andrade, 2019)

No mesmo sentido, destaca-se que a própria redução do caráter conteudista, proposto pela nova BNCC, viabiliza a aproximação com a segunda competência apresentada em seu bojo, que se refere ao exercício do pensamento crítico, inclusive (mas não só) no âmbito científico, pois ao apresentar redução do engessamento e da quantidade de conteúdos, torna-se possível a promoção de conhecimentos mais profundos - inclusive porque o documento seguiu a abordagem de "aprofundar", no Ensino Médio, conteúdos previamente vistos no Ensino Fundamental - o que agrega para o desenvolvimento do pensamento crítico. Por outro lado, não se pode olvidar que a ênfase em conteúdos aplicados, caminha no sentido oposto ao desenvolvimento do pensamento crítico, postulado no âmbito da segunda competência trazida pela BNCC, uma vez que quanto mais superficial e exclusiva/aplicadamente se conhece um conteúdo, menor é possibilidade argumentativa sobre o assunto e, consequentemente, menor o desenvolvimento crítico. Nas palavras de Elisabeth Silva (2003, p. 63), para que o "aluno possa inteirar-se de outros pontos de vista relativos a uma determinada questão, é importante que o professor saiba relacionar um texto a outros textos, que representem outras vozes, outras ideologias", a fim de se obter o desenvolvimento do pensamento crítico. Logo, "leituras" somente aplicadas, uníssonas e superficiais, impedem a fluência completa desse desenvolvimento.

Igualmente, é possível inferir que o novo formato esboçado para o Ensino Médio, talvez por comodidade, em muito pouco difere do que fora apresentado pelo Poder Executivo para os anos finais do Ensino Fundamental (Brasil, 2017). Neste sentido, o novo documento salienta a necessidade de "aprofundar" os conhecimentos já adquiridos quando do curso do nível fundamental (Brasil, 2017). Esta tendência em apresentar conteúdos relacionados à Química, já no Ensino Fundamental, apresenta-se como resultado do que tem sido gerado pela própria globalização, uma vez que aos alunos, cada vez mais jovens, são apresentados conteúdos mais aplicados e superficiais, com velocidade cada vez maior, reduzindo-se, assim, o conhecimento mais aprofundado e o tempo para reflexões mais profundas (Pacheco, 2011). 
Além disso, a proposta trazida pela BNCC vem ao encontro do que tem sido atualmente preconizado como tendência, uma vez que a crítica a um currículo fragmentado, dividido por disciplinas, vem ganhando espaço a cada dia. As modificações na sociedade como um acesso maior a informações, novas tecnologias, novos processos de produção modificaram as relações sociais e produtivas. Têm-se, portanto, parâmetros diferentes de desenvolvimento pessoal. Para isso, competências como criatividade, resolução de problemas e trabalho coletivo ganharam expressão. E para desenvolvimento destas, há que se relacionar essas habilidades com conhecimentos que trabalhem estas características. Por este motivo, há grande defesa de que o currículo seja integrado, enfatizando a interdisciplinaridade em detrimento ao currículo fragmentado (Lopes; de Abreu, 2010).

No mesmo sentido, segundo Bittencourt, o traço delineado pela BNCC segue os princípios que norteiam as políticas internacionais, em que "destaca-se a adoção de uma perspectiva sistêmica para a regulação e gestão da educação, com base na organicidade e na afirmação dos princípios educativos (...), assim como na busca pela denominada qualidade social da educação com base nos padrões mínimos (...)" (Bittencourt, 2017, p. 560), ou seja, embora tenham sido mantidas as autonomias dos entes federativos e unidades escolares em relação aos seus currículos específicos, pretendeu-se a uniformização do ensino no Brasil, sob a égide de padrões mínimos e competências desejáveis.

Ademais, além da discussão de conteúdo já apresentada, no que se refere à nova proposta para o Ensino Médio (da qual a BNCC é um componente) de um modo geral, notou-se uma opção dos elaboradores no sentido de reduzir o acesso do amplo conteúdo aos estudantes, fazendo com que tenham formações restritas e direcionadas, de acordo com a opção escolhida.

A Reforma do Ensino Médio concretizou o entendimento de uma formação para o mercado de trabalho, impedindo que os estudantes tenham acesso a todas as áreas do conhecimento durante boa parte do último ciclo do ensino básico. Além de colocar em xeque conhecimentos científicos cruciais para a formação do pleno cidadão, como filosofia, sociologia, artes e educação física. (Fiorucci; Corrêa, 2018, p. 15)

Ao citar o Projeto Pedagógico do IFPR Jacarezinho, cuja proposta é bastante inovadora e consta como uma das 15 escolas transformadoras do Brasil (Lovato; Franzim, 2017), Fiorucci e Corrêa destacam que o currículo é mais amplo que as definições disciplinares, sendo que as finalidades balizadoras do projeto de educação refletem o tipo de educação pretendida e estas, muito mais que os conteúdos propriamente ditos, "são as que vão nortear o currículo", acrescentando que "A despeito da formalização que se faz ao se desenhar uma trajetória de formação, merece atenção a compreensão de que o currículo precisa ser entendido como uma práxis, ou seja, atualiza-se na prática, consiste em uma narrativa" (2018, p. 23). Neste sentido não se pode ignorar que os cortes proporcionados nos conteúdos de Química e Física, bem como a restrição do acesso aos conteúdos, conforme a opção do estudante, promovem uma modificação no currículo no sentido de formar jovens 
com conhecimento específico, direcionado, tecnicista, implicando, inclusive que os mesmos façam opção por uma área do conhecimento ainda muito jovens. Assim, a Reforma do Ensino Médio no Brasil promove uma precoce escolha da profissão para os jovens e os priva de conhecimentos que os auxiliariam nos aspectos mais básicos do exercício da cidadania (Fiorucci; Correa, 2018).

Além disso, a adolescência é a fase de maior produtividade, velocidade e absorção de informações e conhecimento. Logo, não há sentido em apartar o estudante do conhecimento nesta fase de sua formação - missão esta que deve ser concretizada pelo Ensino Superior, ou mesmo Técnico (Oliveira, 2014). Neste sentido, ao concentrar as três disciplinas em uma única área, a BNCC optou por realizar diversos cortes, principalmente no que tange às disciplinas Química e Física, afastando do aluno o acesso ao conhecimento que dependendo da sua opção no ensino superior (ou técnico) - ele não terá mais. Especificamente neste aspecto, e de forma contrária à proposta geral da BNCC - que se aproxima das teorias críticas e pós-críticas do currículo - esta restrição tangencia um currículo tradicional, tecnicista e voltado ao universo do trabalho (Silva; Alves; Andrade, 2019; Hornburg; Silva, 2007; Young, 2014).

Há que se reconhecer, de todo modo, que muitos conteúdos explícitos nos PCN+, PCNEM e Proposta Curricular do Estado de São Paulo constam na BNCC do Ensino Fundamental, notadamente desde o $6^{\circ}$ ano, tendência também observada em outros países (Pacheco, 2011). Destaca-se aqui, a título de exemplo, apenas a Unidade Temática 'Matéria e energia' na qual aparecem os 'objetos de conhecimento': Misturas homogêneas e heterogêneas; Separação de materiais; Materiais sintéticos; e Transformações químicas conteúdos ou 'objetos' que estavam, de modo claro, nos PCNEM e na Proposta, como conteúdos do Ensino Médio.

Se o 'adiantamento' destes conteúdos em quatro anos letivos for adequado (esta discussão provavelmente será feita pelos pesquisadores da área da Psicologia e da Pedagogia), possivelmente o Ensino Médio poderá, de fato, ter o propósito de criar condições para a complexificação das elaborações, ou seja, para o uso efetivo dos conteúdos aprendidos enquanto recurso para resolução de problemas reais. E, se assim acontecer, ocorrerá um grande salto qualitativo no desenvolvimento acadêmico em termos de apropriação e construção de conhecimentos.

Devido ao fato de este 'adiantamento' acontecer com todos os conteúdos das Ciências Naturais, é necessário que venham a público esclarecimentos relativos ao funcionamento detalhado desta estratégia. Assim, se destaca a necessidade de esclarecer se ocorrerá a melhoria na infraestrutura das escolas, para o ensino de conteúdos que demandam espaços e recursos básicos de laboratório de ciências, por exemplo. Neste quesito, importante lembrar que as melhorias são necessárias de acordo com os novos conteúdos para este nível de ensino, nas escolas de Ensino Fundamental (em sua maioria, gerenciadas pelas prefeituras e não pelo estado, como ocorre com as escolas de Ensino Médio) e, em não ocorrendo tais melhorais, o ensino de transformações químicas etc., pode correr o risco de ser ensinado apenas como ilustração e não como conteúdo apreendido e isso enfraquecerá a efetividade dos objetivos para o Ensino Médio, conforme anunciado na BNCC. 
Espera-se, também, que ocorram discussões acerca dos novos formatos das avaliações nacionais, principalmente dos vestibulares e do ENEM (Exame nacional do Ensino Médio). Isso porque, até o momento da publicação deste texto, não foram apresentados os diagnósticos que relacionem o 'formato das disciplinas' ou 'lugar dos conteúdos' como argumentos para o aumento na aprovação dos exames citados.

Outro ponto que ainda demanda explicação se refere aos impactos desta Reforma nos currículos dos cursos de licenciatura no Ensino Superior e na formação continuada dos professores, tanto de Ciências do Ensino Fundamental quanto de Química do Ensino Médio, pois, para ambos, há "competências e habilidades" implicitamente esperadas, mas para as quais, vistas pelo conteúdo das Diretrizes Curriculares Nacionais para formação de professores e para a área da Química, talvez estes profissionais não tenham sido formados.

\section{Conclusões}

Conclui-se, sucintamente que a BNCC apresenta um projeto que embora robusto, possui lacunas. Além disso, propõe implicitamente certo rompimento com os anteriores documentos orientadores do ensino, no sentido de sequer utilizá-los como referências. Em relação aos demais documentos, os quais têm sido objeto de comparação com a nova Base Curricular, embora suas concepções e abordagens já tenham sido discutidas na literatura, pode-se reafirmar que o caráter com ênfase no conteúdo (e, consequentemente, mais engessado) é observado majoritariamente na Proposta Curricular do Estado de São Paulo. Por sua vez, os PCNEM e os PCN+ são documentos que traçam temas e competências, sendo, portanto, menos rígidos que a Proposta Curricular do Estado de São Paulo.

No que se refere a BNCC, analisar se o documento é adequado, se atende às necessidades do atual Ensino no Brasil, ou se a maneira como tem sido trazido ao professorado - de maneira impositiva ou não - não constituiu a proposta do presente trabalho. Em relação a este aspecto, serão necessários alguns anos até a total adequação à mesma, a fim de que seus efeitos possam ser avaliados.

Embora o próprio texto da BNCC afirme ser um documento normativo, o mesmo mantém a tradição de seus precedentes, qual seja, de documento orientador do ensino, possibilitando não rigidez do sistema, mas sim viabilizando que novos currículos sejam construídos à luz de sua orientação. Sobre o aspecto curricular, não se pode olvidar que embora haja afirmação no sentido de não ser um "novo currículo", mas tão somente um documento para viabilização de "novos currículos", dependendo-se da compreensão que tenha sobre o que é o Currículo, a nova BNCC pode ser entendida como tal. E, assim compreendida, traz em seu corpo, nuances de um currículo que aponta na direção das teorias, ora crítica, ora pós-crítica do currículo, não obstante o fato de orientar no sentido do currículo tradicional quando define que o aluno fique restrito a determinados conteúdos, conforme opção que fizer. Em relação ao conteúdo - não só de Química, mas de Ciências Naturais como um todo - notou-se maior preocupação com a tecnologia, em relação aos documentos anteriores orientadores do ensino, destacadas, principalmente, em relação à 
introdução da biomecânica, bioquímica do DNA e produção de armamentos, inclusive de cunho nuclear. É inegável que a BNCC se apresenta de forma bastante atualizada no que concerne aos expoentes científicos atuais, mais que os próprios documentos anteriores responsáveis pela orientação do ensino se mostraram ao seu tempo.

No que se refere ao esperado para o currículo de Química, tendo em vista a BNCC homologada em 2017, pode-se afirmar que esta área da ciência teve seu espaço reduzido, sendo comprimida pela Biologia. Isto é notório quando se compara a quantidade de conteúdos de teor químico, com os biológicos. Não que entre ambas as áreas das ciências da natureza não possa haver inter ou transdisciplinaridade, no entanto a tendência esperada é a mesma observada no Ensino Fundamental, ou seja, o aluno aprende mais conteúdos atinentes à área de Biologia do que de Química.

Assim, não obstante seu caráter atual, tecnológico e aplicado, certamente a nova Base acentuará os déficits já existentes no âmbito nas ciências da natureza, no que se refere ao ensino de Química, haja vista o fato de que embora já existentes (déficits) em nível Fundamental, eles eram teoricamente suprimidos no Ensino Médio - isso porque no Fundamental o formato observado já prevê maior conteúdo de Biologia do que de Física e Química.

Apesar da falta de clareza a respeito da opção dos estudantes na escolha das disciplinas, trata-se de um problema considerável na formação dos mesmos, isso porque podem estar perdendo oportunidade única de acesso ao conhecimento, numa fase privilegiada para a aprendizagem de conteúdos acadêmicos inter-relacionados com a futura profissão, além do que há a imaturidade dos jovens, no sentido de não estarem preparados para decidir sua formação entre os 14 e 15 anos de idade.

Por fim, em relação ao ensino totalmente contextualizado e aplicado, o cuidado na elaboração dos currículos é imprescindível, haja vista a seriedade do alunado perceber a importância do conhecimento per si e a latente necessidade da redescoberta do prazer pela aquisição deste mesmo conhecimento.

\section{Referências}

ALVES, Jacqueline Querino; SILVA, Francisco de Araújo; ANDRADE, Joana de Jesus. Propostas curriculares e práticas docentes: o que pensam/dizem professores? Revista Brasileira de Pesquisa em Educação em Ciências, v. 16, n. 1, p. 149-165, jan/abr 2016. Disponível em: https://periodicos.ufmg.br/index.php/rbpec/article/view/4341/2907. Acesso em: 06 ago. 2017.

AZANHA, José Mário Pires. Proposta Pedagógica e Autonomia da Escola. Cadernos de História e Filosofia da Educação. 1998, V. 2, n.4, p. 11-21, 1998. Disponível em: http://www3.fe.usp.br/secoes/inst/novo/acervo_jmpa/PDF_SWF/63.pdf. Acesso em: 14 jan. 2019.

BITTENCOURT, Jane. A Base Nacional Comum Curricular: uma análise a partir do ciclo de políticas. In: Educere: XIII Congresso Educacional de Educação. 2017. Anais eletrônicos. Curitiba, Paraná, 2017. 553569 p. Disponível em: https://educere.bruc.com.br/arquivo/pdf2017/24201_12678.pdf. Acesso em: 27 jul. 2020. 
BOGDAN, Robert; BIKLEN, Sari. Investigação qualitativa em educação: uma introdução à teoria e aos métodos. Portugal: Porto Editora, 1994.

BOTH, Luiz. A Química Orgânica no Ensino Médio: na sala de aula e nos livros didáticos. 2007. 152f. Dissertação (Mestrado) - Instituto de Educação da Universidade Federal de Mato Grosso, Cuiabá.

BOURDIEU, Pierre; PASSERON, Jean-Claude. A reprodução. 3.ed. Rio de Janeiro: Francisco Alves, 1992.

BRASIL. Constituição da República Federativa do Brasil. Brasília, 1988. Disponível em: http://www.planalto.gov.br/ccivil_03/constituicao/constituicaocompilado.htm. Acesso em: 06 ago. 2017.

BRASIL. Lei $\mathrm{n}^{\circ}$ 9.394, de 20 de dezembro de 1996. (LDB) Brasília, 1996. Disponível em: http://www.planalto.gov.br/ccivil_03/leis/L9394.htm. Acesso em: 06 ago. 2017.

BRASIL. Lei $\mathrm{n}^{\mathrm{o}} 13.415 / 2017$, de 16 de fevereiro de 2017. Disponível em: http://www.planalto.gov.br/ccivil_03/_ato2015-2018/2017/Lei/L13415.htm Acesso em: 08 ago. 2017.

BRASIL. MEC. Base Nacional Comum Curricular: Educação é a base. Brasília, 2017. Disponível em: http://basenacionalcomum.mec.gov.br/wpcontent/uploads/2018/06/BNCC_EnsinoMedio_embaixa_site_110518.pdf. Acesso em: 15 out. 2018.

BRASIL. MEC. Parâmetros Curriculares Nacionais para o Ensino Médio: Parte III. Brasília, 2000. Disponível em: http://portal.mec.gov.br/seb/arquivos/pdf/14_24.pdf. Acesso em: 20 jul. 2017.

BRASIL. Secretaria da Educação Média e Tecnológica. PCN+ Ensino Médio: Orientações Educacionais complementares aos Parâmetros Curriculares Nacionais - Ciências da Natureza, Matemática e suas Tecnologias. Brasília: MEC/SEMTEC, 2002. Disponível em: http://portal.mec.gov.br/seb/arquivos/pdf/CienciasNatureza.pdf. Acesso em: 17 jun. 2017.

FIORUCCI, Rodolfo; CORRÊA, Hugo Emmanuel da Rosa. As unidades curriculares (UC) como inovação na Educação: experiência de gestão, história e politecnia. In: CORRÊA, Hugo Emmanuel da Rosa; FIORUCCI, Rodolfo; DA PAIXÃO, Sergio Vale (Org.). Currículo Inovador: Experiências didáticas no IFPR Jacarezinho. (Org.) Curitiba: Editora IFPR, 2018. p. 10 - 36.

GALIAN, Cláudia Valentina Assumpção; LOUZANO, Paula Baptista Jorge. Michael Young e o campo do currículo: da ênfase no "conhecimento dos poderosos" à defesa do "conhecimento poderoso". Educação e Pesquisa, v. 40, n. 4, p. 1109-1124, out/dez 2014. Disponível em: https://doi.org/10.1590/s151797022014400400201. Acesso em: 26 jul. 2020.

HORNBURG, Nice; SILVA, Rúbia. Teorias sobre currículo: uma análise para compreensão e mudança. Revista de divulgação técnico-científica do ICPG. v. 3, n. 10, p. 61-66, jan.-jun. 2007.

LEMOS, Ligia Maria Prezia. Nuvem de tags como ferramenta de análise de conteúdo: uma experiência com as cenas estendidas da telenovela Passione na internet. Lumina, v.10 n. 1, p. 1-18, abr, 2016. Disponível em: https://periodicos.ufjf.br/index.php/lumina/article/view/21192/11526. Acesso em: out. de 2018.

LOPES, Alice Casimiro; DE ABREU, Rozana Gomes. A Interdisciplinaridade a partir das políticas de currículo. In: dos Santos, Wildosn Luiz P.; Maldaner, Otavio Aloisio (Org.). O Ensino de Química em foco. Ijuí: Editora Unijuí, 2010. p. 77-99.

LOPES, Alice Casimiro. Os Parâmetros Curriculares Nacionais Para o Ensino Médio e a Submissão ao Mundo Produtivo: o caso do conceito de contextualização. Educação \& Sociedade, v. 23, n. 80, set. 2002.

LOVATO, Antonio; FRANZIM, Raquel. O ser e o agir transformador: para mudar a conversa sobre educação. 1 ed., São Paulo: Instituto Alana: Ashoka Brasil, 2017. Disponível em: http://escolastransformadoras.com.br/wp-content/uploads/2017/09/Livro_Ser_Agir_TransformadorEscolas-ransformadoras.pdf. Acesso em: jan. de 2019.

LUCCAS, Simone; BATISTA, Irinéa de Lourdes. O papel da matematização em um contexto interdisciplinar no ensino superior. Ciência e Educação, v.17, n. 2, p.451-468, 2011. Disponível em: http://dx.doi.org/10.1590/S1516-73132011000200013. Acesso em: 01 ago. 2020. 
LÜDKE, Menga; ANDRÉ, Marli E. D. A. Pesquisa em educação: abordagens qualitativas. São Paulo: EDU, 1986.

MELO, Myllena Cândida; VASCONCELLOS-SILVA, Paulo Roberto. Uso de comunidades virtuais no suporte a portadoras de câncer de mama. Ciência \& Saúde coletiva, v. 23, n. 10, p. 3347-3356, out., 2018. Disponível em: https://www.scielosp.org/article/csc/2018.v23n10/3347-3356/. Acesso em: out. de 2018.

MINAYO, Maria Cecília de Souza. O desafio do conhecimento: pesquisa qualitativa em saúde. São PauloRio de Janeiro: Hucitec-Abrasco, 1992.

NUNES, Albino Oliveira; NUNES, Albano Oliveira. PCN - conhecimentos de química, um olhar sobre as orientações curriculares oficiais. Holos, Ano 23, Vol. 2 - 2007.

OLIVEIRA, Gilberto Gonçalves de. Neurociências e os processos educativos: um saber necessário na formação de professores. Revista Educação, 18 n. 1, p. 13-24, jan./abr., 2014.

PACHECO, José Augusto. Currículo, Aprendizagem e Avaliação. Uma abordagem face à agenda globalizada. Revista Lusófona de Educação, v. 17, n. 17, p. 75-90, ago., 2011. Disponível em: https://revistas.ulusofona.pt/index.php/rleducacao/article/view/2366. Acesso em: jan. de 2019.

PRAIS, Jacqueline Lidiane de Souza; ROSA, Vanderley Flor da. Nuvem de palavras e mapa conceitual: estratégias e recursos tecnológicos na prática pedagógica. Nuances: estudos sobre Educação, v. 28, n. 1, p. 201-219, jan./abr., 2017. Disponível em: http://revista.fct.unesp.br/index.php/Nuances/article/view/4833. Acesso em: 13 out. 2018.

SANTOS, Joyce Cristina da Cruz. Vamos passear na floresta, enquanto seu lobo não vem: reflexões sobre a química orgânica no ensino médio. Monografia (Licenciatura em Química). 2008. 53 f. - Instituto de Ciências Exatas da Universidade Federal de Minas Gerais, Belo Horizonte, 2008.

SÃO PAULO (Estado). Secretaria da Educação. Proposta curricular do Estado de São Paulo / Coord. Maria Inês fini. São Paulo: SEE, 2008.

SÃO PAUlO (Estado). Currículo Paulista: Ensino Médio. 2020. Disponível em: https://efape.educacao.sp.gov.br/curriculopaulista/ensino-medio/. Acesso em: 01 ago. 2020.

SAVIANI, Dermeval. Desafios da construção de um sistema nacional articulado de educação. Trabalho, Educação e Saúde, v. 6, n. 2, p. 213-232, oct. 2008. Disponível em: https://www.scielo.br/pdf/tes/v6n2/02.pdf. Acesso em: 28 jul. 2020.

SILVA, Elisabeth Ramos da. O desenvolvimento do senso crítico no exercício de identificação e escolha de argumentos. Revista Brasileira de Linguística Aplicada, v.3, n .1, p. 57-68, 2003. Disponível em: https://www.scielo.br/pdf/rbla/v3n1/05.pdf. Acesso em: 02 ago. 2020.

SILVA, Francisco de Araújo; ALVES, Jacqueline Querino; ANDRADE, Joana de Jesus. 2019. O livro didático como documento histórico para análise do currículo de Química e Ciências. Revista Triângulo, v. 12, n. 1, p. 43-67, jan/abr. 2019. Disponível em:http://seer.uftm.edu.br/revistaeletronica/ index.php/revistatriangulo/article/view/3583/3470. Acesso em: 08 ago. 2017.

SILVA, Monica Ribeiro da. A BNCC da reforma do ensino médio: o resgate de um empoeirado discurso. Educação em Revista, v. 34, e214130, out., 2018. Disponível em https://www.scielo.br/pdf/edur/v34/1982-6621-edur-34-e214130.pdf. Acesso em: 04 mar. 2019.

SILVA, Tomaz Tadeu da. Documentos de identidade: uma introdução às teorias do currículo. Belo Horizonte: Autêntica, 1999.

YOUNG, Michael. Teoria do currículo: o que é e por que é importante. Cadernos de Pesquisa, São Paulo, v. 44, n. 151, p. 190-202, mar., 2014 . Disponível em: https://www.scielo.br/pdf/cp/v44n151/10.pdf. Acesso em: 15 out. 2018. 


\section{Correspondência}

Jacqueline Querino Alves: Doutora em Ciências pela Faculdade de Filosofia Ciências e Letras de Ribeirão Preto (USP); Mestra em Ciências pela Faculdade de Filosofia Ciências e Letras de Ribeirão Preto (USP); Graduada em Química Licenciatura, pela Faculdade de Filosofia Ciências e Letras de Ribeirão Preto (USP). Professora de Ciências na Prefeitura Municipal de Ribeirão Preto. Bacharel em Direito, pela Faculdade de Ciências Jurídicas e Sociais Laudo de Camargo (UNAERP). Mestre em Direito Processual Civil Coletivo (UNAERP). Advogada.

E-mail: jacqueline.querino.alves@gmail.com

Tássia Joi Martins: Doutora em Ciências pela Faculdade de Filosofia Ciências e Letras de Ribeirão Preto (USP); Mestra em Química pela Universidade Federal de São Carlos (UFSCar); Licenciada em Química pela Universidade Federal de São Carlos (UFSCar). Tem experiência como professora de Ensino Fundamental e Médio e docente no Ensino Superior.

E-mail: tassiajoi@gmail.com

Joana de Jesus Andrade: Pós-Doutorado em Educação pela Universidade de Campinas (UNICAMP); Doutora em Educação pela Universidade de Campinas (UNICAMP); Mestra em Educação pela Universidade Regional do Noroeste do Estado do Rio Grande do Sul (UNIJUÍ); Especialista em Instrumentação para o ensino de Ciências (UNICENTRO); Licenciada em Ciências Naturais e em Biologia pela Universidade Estadual do Centro-Oeste (UNICENTRO). Professora Doutora do Departamento de Química (Licenciatura) da Faculdade de Filosofia, Ciências e Letras de Ribeirão Preto (USP); Professora do Programa de Pós-Graduação em Educação da FFCLRP-USP; Professora do Programa de Mestrado Profissional em Química em Rede Nacional - PROFQUI.

E-mail: joanaj@ffclrp.usp.br

Texto publicado em Currículo sem Fronteiras com autorização das autoras 